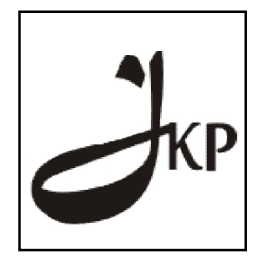

Jurnal Konseling dan Pendidikan

ISSN Cetak: 2337-6740 - ISSN Online: 2337-6880

http://jurnal.konselingindonesia.com

Volume 3 Nomor 3, November 2015, HIm 41-46

Info Artikel:

Diterima 12/10/2015

Direvisi 14/11/2015

Dipublikasikan 28/11/2015

\title{
PENERAPAN METODE INKUIRI UNTUK MATERI PENGEMBANGAN DIRI (PKN) PADA SISWA KELAS V SD NEGERI 26 NANGGALO KECAMATAN KOTO XI TARUSAN
}

\section{MASLINDA}

Abstrak

Pendidik harus bisa menyiapkan anak didik menjadi orang dewasa yang mandiri, mampu menggunakan dan mengembangkan sendiri kemampuan (pengetahuan dan keterampilan) yang telah dimilikinya, dan mempunyai sikap yang sesuai dengan norma-norma yang berlaku di masyarakat. Secara umum tujuan penelitian ini adalah untuk memberikan gambaran/informasi bagi guru PKn tentang pengaruh metode inkuiri dalam pembelajaran PKn di Kelas V SD. Penelitian ini menggunakan metode penelitian tindakan kelas. Subjek penelitian adalah siswa Kelas VI SD Negeri 26 Nanggalo, dengan jumlah siswa 30 orang terdiri atas 14 orang laki-laki dan 16 orang perempuan. Hasil penelitian menunjukkan bahwa nilai rata-rata siswa sebelum menggunakan metode inkuiri 5,7 sedangkan sesudah menggunakan metode inkuiri meningkat menjadi 7,46, terdapat selisih nilai sebesar 1,76. Selain data yang dihasilkan dari tes, terdapat data lain yang berupa hasil wawancara tentang kesan pembelajaran dengan menggunakan metode inkuiri. Sebanyak 16 siswa (56,5\%) mengakui bahwa belajar dengan menggunakan metode inkuiri sangat menarik dan dapat cepat dipahami, sedangkan sebanyak 14 siswa (43,5\%) mengatakan bahwa pembelajaran terkesan sama saja dengan menggunakan metode inkuiri ataupun metode lain.

Keyword: Penerapan Metode Inkuiri;PKN; SD.

Copyright (C) 2015 IICET (Padang - Indonesia) - All Rights Reserved

Indonesian Institute for Counseling, Education and Theraphy (IICET)

\section{PENDAHULUAN}

Tujuan pendidikan nasional untuk meningkatkan kualitas manusia Indonesia, yaitu beriman dan bertaqwa terhadap Tuhan Yang Maha Esa, berbudi pekerti luhur, berkepribadian, berdisiplin, bekerja keras, tangguh, bertanggungjawab, mandiri, cerdas dan terampil serta sehat jasmani dan rohani.Pendidikan nasional juga harus mampu menumbuhkan dan memperdalam rasa cinta pada tanah air, mempertebal semangat kebangsaan dan rasa kesetiakawanan sosial.Dalam dunia pendidikan kita sering mendengar ungkapan yang cukup sederhana yaitu "mendidik anak pada masa kini berarti menyiapkan orang dewasa di masa mendatang".Pendidik harus bisa menyiapkan anak didik menjadi orang dewasa yang mandiri, mampu menggunakan dan mengembangkan sendiri kemampuan (pengetahuan dan keterampilan) yang telah dimilikinya, dan mempunyai sikap yang sesuai dengan norma-norma yang berlaku di masyarakat.

Guru dapat mewujudkan tujuan pendidikan nasional dengan mengembangkan iklim pembelajaran yang dapat menumbuhkan rasa percaya diri serta sikap dan perilaku yang inovatif dan kreatif. Dengan demikian pendidikan nasional akan mampu mewujudkan manusia pembangunan yang dapat membangun dirinya sendiri serta bersama-sama bertanggung jawab atas utuhnya Negara Kesatuan Republik Indonesia.

Pendidikan Pancasila dan Kewarganegaraan (PKn) yang sesuai dengan isi Kurikulum 2004 adalah pendidikan tentang nilai-nilai yang sasarannya bukan semata-mata pengalihan pengetahuan melainkan lebih ditekankan pada pembentukan sikap (Depdikbud:1994). Lebih lanjut dijelaskan bahwa PKn merupakan salah satu mata pelajaran yang digunakan sebagai wahana untuk mengembangkan dan melestarikan nilai luhur dan moral yang berakar pada budaya bangsa Indonesia (Depdikbud:1994). Mata pelajaran PKn meliputi ranah kognitif, afektif dan psikomotor, yang lebih menitikberatkan pada ranah afektif.Kepribadian siswa pada hakikatnya dipengaruhi oleh ranah kognitif, apektif dan psikomotor.Ketiga ranah tersebut menyatu dan sulit dipisahkan satu dengan yang lainnya, sehingga membentuk kepribadian unik setiap manusia.Dalam menyajikan pelajaran, guru harus berupaya mengembangkan ketiga ranah tersebut agar berkembang sesuai dengan yang diharapkan.Dalam pelaksanaan pembelajaran terdapat perbedaan penekanan dari ketiga ranah. Pembelajaran PKn lebih menekankan 
pada pengembangan ranah apektif yang sesuai dengan nilai dan norma yang berlaku dan berkembang dalam tatanan kehidupan manusia Indonesia.

Pada proses pembelajaran PKn, belum semua guru melaksanakan pendekatan siswa aktif, dan peran guru sebagai dinamisator belum diterapkan. Guru masih dominan menggunakan metode ceramah dan tanya jawab. Dalam penyampaian materi pelajaran guru masih menggunakan buku-buku sumber dan buku pelengkap sebagai sumber belajar. Saat menjelaskan materi pembelajaran kepada siswa, guru belum menggunakan media pembelajaran yang lain. Untuk pemahaman nilai dalam PKn, terdapat beberapa metode yang dapat dilaksanakan dan dikembangkan oleh guru di antaranya ceramah, tanya jawab, diskusi, karyawisata, pemecahan masalah, pembinaan nilai, simulasi, inkuiri, bermain peran, permainan, tugas, drill (Depdikbud, 1996:50).

Studi awal yang penulis lakukan pada guru Kelas V SD Negeri 26 Nanggalo Kecamatan Koto XI Tarusan, Kabupaten Pesisir Selatan, terlihat guru belum menggunakan metode yang tepat untuk setiap materi pembelajaran. Metode yang sering digunakan oleh guru dalam mengajar masih sebatas ceramah dan tanya jawab. Dalam penelitian ini penulis akan mencobakan pembelajaran PKn dengan menggunakan metode inkuiri yang merupakan metode yang belum pernah dicobakan sebelumnya pada siswa.Metode inkuiri, menurut Depdikbud (1996.-76), adalah "Sebuah pendekatan yang digunakan dalam proses belajar mengajar yang mana siswa dihadapkan pada suatu keadaan atau masalah untuk kemudian dicari jawaban atau kesimpulannya".

Rumusan masalah dalam penelitian yaitu bagaimanakah cara melaksanakan proses pembelajaran PKn dengan metode inkuiri di Kelas V SD Negeri 26 Nanggalo pada Pokok Bahasan Pengendalian Diri Menghargai Keputusan Bersama?Penelitian ini bertujuan untuk mendapatkan gambaran tentang pelaksananaan pembelajaran PKn dengan metode inkuiri di Kelas V SD Negeri 26 Nanggalo pada Pokok Bahasan Pengendalian Diri Menghargai Keputusan Bersama.

\section{METODOLOGI PENELITIAN}

Penelitian ini merupakan penelitian tindakan kelas dengan dua siklus. Langkah penelitian setiap siklus merujuk pendapat Suharsimi Arikunto (2007:16)yang terdiri dari empat langkah yaitu: perencanaan, pelaksanaan tindakan, observasi/pengamatan, dan refleksi. Subjek penelitian ini adalah siswa Kelas V SD Negeri 26 Nanggalo, jumlah siswa 30 orang terdiri dari 14 orang laki-laki dan 16 orang perempuan.Penelitian Tindakan kelas dilaksanakan pada awal bulan Maret 2015.

Rancanganpembelajaran menggunakan metode inkuiri untuk penelitian ini disajikan berikut ini.

Persiapan Pembelajaran

1. Guru merumuskan masalah pengendalian diri sebagai topik pembahasan dengan metode inkuiri untuk mengembangkan perbuatan luhur yang mencerminkan kematangan mental dan prilaku

2. Guru mempersiapkan bahan tes tentang pengendalian diri

3. Guru mempersiapkan penjelasan langkah-langkah kegiatan proses pembelajaran dengan metode inkuiri

4. Guru mempersiapkan bahan pelajaran tentang pengendalian diri melalui proses inkuiri sehingga siswa dapat menyebutkan pengertian pengendalian diri dalam keluarga, sekolah dan lingkungan masyarakat dan memahami dan menjelaskan pentingnya pengendalian diri sehingga siswa bersedia menahan diri bila menghadapi masalah.

Tujuan Pembelajaran Umum

1. Memahami perlunya kemauan untuk mengendalikan diri dalam kehidupan bermasyarakat, berbangsa, dan bernegara.

2. Membiasakan berperilaku sabar, tidak cepat marah, tidak serakah dan tidak melakukan perbuatan yang merugikan orang lain.

Tujuan Pembelajarau Khusus

1. Melalui metode inkuiri siswa dapat mengendalikan diri dari perilaku yang kurang baik

2. Melalui metode inkuiri siswa dapat menghindari perbuatan yang merugikan orang lain

3. Melalui metode inkuiri siswa dapat mengendalikan diri tidak memaksakan kehendak kepada orang lain

4. Melalui metode inkuiri siswa dapat menghormati dan menghargai hak-hak Orang lain di sekitar kita

5. Melalui metode inkuiri siswa dapat membuat kesimpulan tentang perlunya bersikap rendah hati sebagai wujud pengendalian diri yang baik

6. Melalui metode inkuiri siswa dapat memelihara benda/fasilitas untuk kepentingan bersama/umum

Langkah-Langkah Pembelajaran 
a. Stimulus

Guru memberikan tes pendahuluan sebagaimana yang telah dipersiapkan. Siswa menjawab pertanyaan dengan menyatakan benar atau salah

b. Masalah yang akan dicari pemecahannya

Guru memberikan penjelasan tentang topik pembelajaran yaitu Pengendalian Diri yang akan dibahas dan dicari jawabannya/dipecahkan masalahnya melalui metode inkuiri.

c. Perumusan Masalah

Bagaimana cara mengendalikan diri di rumah ?

Bagaimana cara mengendalikan diri di sekolah?

Bagaimana cara mengendalikan diri di lingkungan masyarakat?

Pencarian pemecahan masalah

a. Menyiapkan media, alat peraga dan bahan yang diperlukan

b. Guru mengarahkan perhatian siswa pada keadaan anggota keluarga di rumah yang mempunyai kepentingan yang tidak sama, teman di sekolah yang berbeda karakter dan sifatnya, keadaan di lingkungan masyarakat yang bersifat heterogen

c. Setalah siswa diberi kesempatan bertukar pikiran dengan teman sekelompoknya, siswa menjawab pertanyaanpertanyaan guru yang diajukan menuju kepada kesimpulan akhir. (sebagai stimulus dalam merangsang siswa untuk dapat memecahkan masalah)

\section{HASIL DAN PEMBAHASAN PENELITIAN \\ HASIL PENELITIAN \\ Pelaksanaan}

Siswa dibagi menjadi 4 kelompok tiap kelompok mendapat lembar kerja yang berisi permasalahan yang harus dipecahkan. Guru memberikan stimulus (memberikan pertanyaan-pertanyaan yang dijawab oleh siswa secara lisan atau tertulis);

$\checkmark$ Mengapa terjadi pertengkaran kecil di rumah Adi?

Jawaban Siswa : Karena acara yang ditonton oleh Adi sangat bagus (Imas Yuliani)

Karena lbunya tidak suka pada acara anak-anak (Hedi Riyana)

Karena kakak Adi sedang sakit (Laeli)

$\checkmark$ Bagaimana agar tidak terjadi pertengkaran seperti di atas?

Jawaban siswa :

Suara TVnya jangan terlalu besar (Meti)

Adi sebaiknya tidak nonton TV tapi menghapal pelajaran (Ninik)

$\checkmark$ Deden bagaimana menurut pendapatmu?

Deden tidak menjawab

Jawaban siswa

Harusnya Adi tidak menonton TV karena kakaknya sedang sakit (Alfina)

Saya setuju dengan pendapat Alfina (Astri)

$\checkmark$ Guru memperlihatkan gambar Adi sedang bertengkar dengan kakaknya kemudian bertanya pada siswa: Mengapa Adi dan kakaknya bertindak seperti itu?

Jawaban siswa: Karena kakaknya tidak mau mengalah (Alfina )

$\checkmark$ Guru bercerita bahwa Adi tidak menontan TV karena kakaknya sakit, lalu bertanya "Apakah tindakan Adi merupakan pengendalian diri ?

Jawaban Siswa :Ya (Alfina ) lalu bertanya Bagaimana cara pengendalian diri di rumah?

Jawaban Siswa: harus bisa melihat apakah perbuatan kita merugikan orang lain atau tidak. Jika merugikan maka perbuatan itu jangan dilakukan karena orang lain akan rugi (Alfina).

\section{Pengamatan}

Hasil belajar siswa pada siklus I dan II dapat dilihat pada tabel berikut ini. 
Tabel 1

Hasil Belajar Siswa Pada Siklus I dan II

\begin{tabular}{|c|c|c|c|c|}
\hline No. & Nama Siswa & Siklus I & Siklus II & Ket. \\
\hline 1 & Hegiva Duanda Putra & 6 & 6 & \\
\hline 2 & Tona Natalia Saputri & 5 & 6 & \\
\hline 3 & Edo Saputra & 5 & 8 & \\
\hline 4 & Igo Dwi Putra & 5 & 8 & \\
\hline 5 & Ipil Defriandi & 5 & 9 & \\
\hline 6 & Jufriandi & 5 & 7 & \\
\hline 7 & Refil Adiguna & 8 & 8 & \\
\hline 8 & Aldi Permana & 7 & 8 & \\
\hline 9 & Alhadid Norismanto & 8 & 8 & \\
\hline 10 & Laded Dwi Putra & 5 & 8 & \\
\hline 11 & Rike Yoza Putri & 5 & 7 & \\
\hline 12 & Zeldi Putra & 7 & 9 & \\
\hline 13 & Alfin Dinata & 7 & 8 & \\
\hline 14 & Devi Rahma Aulan & 6 & 7 & \\
\hline 15 & Irfan Putra & 5 & 7 & \\
\hline 16 & Jovan Febra Wijaya & 4 & 7 & \\
\hline 17 & M. Zola Putra & 5 & 7 & \\
\hline 18 & Ribi Tri Marta & 5 & 6 & \\
\hline 19 & Riski Pardo & 5 & 7 & \\
\hline 20 & Radif Dinasares & 6 & 8 & \\
\hline 21 & Rifki Saputra & 7 & 8 & \\
\hline 22 & Sugeng Maulana & 5 & 7 & \\
\hline 23 & Nanang Hidayat & 6 & 8 & \\
\hline 24 & Zeli Sudasni & 7 & 8 & \\
\hline 25 & Zend Kiadi & 6 & 7 & \\
\hline 26 & Nesa Afriani & 5 & 7 & \\
\hline 27 & Fran Pandu.D. & 5 & 7 & \\
\hline 28 & Dian Oktpri & 6 & 8 & \\
\hline 29 & Edi Yantomas & 4 & 6 & \\
\hline \multirow[t]{3}{*}{30} & Rosy Ahmadi & 5 & 7 & \\
\hline & Jumlah & 170 & 222 & \\
\hline & Rata-rata & 5,696 & 7,457 & \\
\hline
\end{tabular}

Penerapan metode inkuiri pada pembelajaran PKn di Kelas V SD Negeri 26 Nanggalo pada pokok bahasan Pengendalian Diri, mendapatkan hasil belajar yang baik. Hal ini terbukti dari hasil rata-rata nilai pada siklus II sebesar 7,46 sedangkan sebelumnya nilai rata-rata hanya mencapai 5,7. Pembelajaran PKn dengan menggunakan metode inkuiri lebih efektif karena siswa dilibatkan secara aktif, sehingga proses pembelajaran dapat menggairahkan siswa.

Pada awal pembelajaran dengan menggunakan metode inkuiri perhatian siswa sudah menunjukkan respon yang positif, apalagi sewaktu siswa menjawab pertanyaan-pertanyaan guru yang berhubungan dengan 
Pengendalian Diri.Siswa lebih antusias dan merasa tertantang untuk mencari dan menemukan jawaban atas pertanyaan-pertanyaan yang diajukan guru.Melalui alat peraga yang telah disediakan, tampak bahwa setiap siswa ingin menanggapi peristiwa yang terjadi dalam gambar sehingga pembelajaran tampak lebih hidup.Siswa berdiskusi dengan teman sekelompaknya untuk memecahkan permasalahan yang diajukan guru.

Dengan adanya bimbingan guru (berupa pertanyaan-pertanyaan) yang terus menerus dan berkesinambungan akhirnya siswa dapat menemukan konsep tentangpengendalian diri.

Selain data yang dihasilkan dari tes, terdapat data lain yang berupa hasil wawancara tentang kesan siswa terhadap pembelajaran menggunakan metode inkuiri. Sebanyak 16 siswa (56,5\%) mengakui bahwa belajar dengan menggunakan metode inkuiri sangat menarik dan dapat cepat dipahami, sedangkan sebanyak 14 siswa (43,5\%) mengatakan bahwa pembelajaran terkesan sama saja dengan menggunakan metode inkuiri ataupun metode lain. Hasil wawancara dengan siswa diketahuibahwapembelajaran PKn menggunakan metode inkuiri membuat mereka lebih termotivasi dan bergairah untuk belajar.Keberhasilan penerapan metode ini tidak terlepas dari prosedur perencanaan yang telah disusun penulis dalam menerapkan metode inkuiri tersebut.

\section{PEMBAHASAN}

Metode inkuiri dalam pembelaiaran PKn di Kelas V SD Negeri 26 Nanggalo, pada pokok bahasan Pengendalian Diri dikembangkan atas dasar hasil temuan data yang dikaitkan dengan konsep dan teori yang relevan.Pembelajaran PKn menggunakan metode inkuiri dalam pembelajaran PKn di Kelas V SD Negeri 26 Nanggalo, ternyata dapat menarik minat siswa. Siswa lebih antusias dan bergairah karena merasa dilibatkan dalam proses pembelajaran. Hal ini bisa dilihat sewaktu siswa menjawab pertanyaan guru dan ketika siswa melakukan diskusi. Pembelajaran PKn yang disajikan dengan cara melibatkan siswa secara aktif dalam menemukan konsep akhir (kesimpulan) sangat menarik bagi siswa. Hal ini sesuai dengan pendapat Djamariah dan Zain (1997:22)."Inquiry adalah belaiar mencari dan menemukan sendiri.Dalam sistem belajar ini guru menyajikan bahan pelajaran tidak dalam bentuk final, tetapi siswa diberi peluang untuk mencari dan menemukan sendiri dengan menggunakan teknik pendekatan masalah".Dengan menggunakan metode ini siswa bebas mengungkapkan pendapatnya dalam memecahkan masalah yang telah ditetapkan, sehingga siswa merasa tertantang untuk aktif mencari dan menemukan kesimpulan dari hasil diskusi dan pengematan terhadap media pelajaran berupa gambar

Guru membimbing dengan pertanyaan-pertanyaan yang berkesinambungan selama siswa mengamati peristiwa yang terjadi pada gambar.Akhirnya siswa dapat menemukan konsep akhir (kesimpulan) dari hasil pengamatannya.Pertanyaan dari guru memegang peranan penting dalam menerapkan metode ini, karena itu dianjurkan agar guru mengajukan pertanyaan-pertanyaan yang menuntut siswa berpikir tingkat tinggi. Bimbingan guru yang berupa pertanyaan tersebut dimaksudkan agar dalam proses belajar siswa dapat mengembangkan potensinya secara optimal dalam menemukan konsep akhir (kesimpulan) dari hasil pengamatannya. Hal tersebut sesuai dengan yang diungkapkan oleh Ahmad (1996:95) bahwa bimbingan dalam belajar difokuskan kepada permasalahan tentang bagaimana caranya agar anak dapat terhindar dari kegagalan, mampu mengatasi hambatanhambatan serta kesulitan hingga dapat mencapai prestasinya dengan mengembangkan dirinya sendiri secara optimal dalam menempuh proses belajar". Berdasarkan pendapat di atas apabila guru kurang terampil di dalam memberikan bimbingan (mengajukan pertanyaan-pertanyaan) maka akan menjurus kepada kerancuan atau kekeliruan materi yang dipelajari.

\section{KESIMPULAN DAN SARAN KESIMPULAN}

Berdasarkan pengolahan dan analisis data yang diperoleh dalam menerapkan metode inkuiri, maka penulis menarik kesimpulan bahwa Pembelajaran dengan menggunakan metode inkuiri lebih menarik minat siswa. Siswa lebih antusias dan lebih bergairah dalam belajar, karena merasa dilibatkan di dalam proses pembelajaran. Hasil belajar dengan menggunakan metode inkuiri lebih baik dibanding dengan tidak menggunakan metode inkuiri.

\section{SARAN}

Melalui penelitian ini, penulis merasa perlu menyampaikan saran-saran sebagai bahan untuk dijadikan kajian dan pertimbangan bagi guru yaitu sebaiknya dalam mengajarkan PKn menggunakan berbagai metode, pendekatan dan teknik yang beragam.Dengan menggunakan metode inkuri siswa menjadi tertantang dan aktif menjawab setiap pertanyaan guru.Alokasi waktu untuk pokok bahasan pengendalian Diri perlu ditambah sesuai 
kebutuhan dengan cara mengambil dari pokok bahasan lain yang ruang lingkupnya tidak terlalu luas. Sekolah agar dapat melengkapi sarana pembelajaran PKn untuk menambah semangat belajar dan menunjang lancarnya proses pembelajaran, baik berupa gambar atau alat elektronik lain yang dapat memutar film.

\section{DAFTAR PUSTAKA}

Ahmad, Djauzak, 1996, Pedoman Pelaksanaan PBM di SD, Jakarta: Depdikbud

Depdikbud.1994. Kurikulum Pendidikan Dasar.Jakarta: Depdikbud

------ 1996. Materi Latihan Kerja Guru PKn. Jakarta: Depdikbud

Djamariah, BS dan Zain, Azwan. 1997. Strategi Belajar Mengajar. Jakarta: PT Rineka Cipta.

Suharsimi Arikunto. 2007. Penelitian Tindakan Kelas. Jakarta: Bumi Aksara 